\title{
Trees Increase Ant Species Richness and Change Community Composition in Iberian Oak Savannahs
}

\author{
Álvaro Gaytán ${ }^{1, * \mathbb{D}}$, José L. Bautista ${ }^{2}$, Raúl Bonal ${ }^{2,3}{ }^{\circledR}$, Gerardo Moreno ${ }^{2} \mathbb{D}$ and Guillermo González-Bornay ${ }^{2}$ \\ 1 Department of Ecology, Environment and Plant Sciences, Stockholm University, 114-18 Stockholm, Sweden \\ 2 Grupo de investigación Forestal, INDEHESA, University of Extremadura, 10600 Plasencia, Spain; \\ josephbirdlife@gmail.com (J.L.B.); raulbonal@unex.es (R.B.); gmoreno@unex.es (G.M.); \\ bornay@unex.es (G.G.-B.) \\ 3 Department of Biodiversity, Ecology and Evolution, Complutense University of Madrid, 28040 Madrid, Spain \\ * Correspondence: alvaro.gaytan@su.se
}

Citation: Gaytán, Á.; Bautista, J.L.; Bonal, R.; Moreno, G.;

González-Bornay, G. Trees Increase Ant Species Richness and Change Community Composition in Iberian Oak Savannahs. Diversity 2021, 13, 115. https://doi.org/10.3390/ d13030115

Academic Editor: Luc Legal

Received: 8 February 2021

Accepted: 4 March 2021

Published: 7 March 2021

Publisher's Note: MDPI stays neutral with regard to jurisdictional claims in published maps and institutional affiliations.

Copyright: () 2021 by the authors. Licensee MDPI, Basel, Switzerland. This article is an open access article distributed under the terms and conditions of the Creative Commons Attribution (CC BY) license (https:// creativecommons.org/licenses/by/ $4.0 /)$.

\begin{abstract}
Iberian man-made oak savannahs (so called dehesas) are traditional silvopastoral systems with a high natural value. Scattered trees provide shelter and additional food to livestock (cattle in our study sites), which also makes possible for animals depending on trees in a grass-dominated landscape to be present. We compared dehesas with nearby treeless grasslands to assess the effects of oaks on ant communities. Formica subrufa, a species associated with decayed wood, was by far the most abundant species, especially in savannahs. Taxa specialized in warm habitats were the most common both in dehesas and grasslands, as expected in areas with a Mediterranean climate. Within dehesas, the number of species was higher below oak canopies than outside tree cover. Compared to treeless grasslands, the presence of oaks resulted in a higher species richness of aphid-herding and predator ants, probably because trees offer shelter and resources to predators. The presence of oaks changed also the species composition, which differed between grasslands and dehesas. In self-standing scattered oaks, ant communities did not differ between the trunks and soil below canopies. These results stress the conservation value of trees in dehesas; within grasslands, they offer an additional microhabitat for species that would otherwise be scarce or absent.
\end{abstract}

Keywords: ants; biodiversity; bioindicators; functional groups; dehesas; resource specialization

\section{Introduction}

Both farmers and conservationists acknowledge the value of traditional silvopastoral systems for sustainable food production and biodiversity [1,2]. In Europe, the largest extensions of silvopastoral systems are usually in areas in which environmental restrictions (e.g., poor soils and harsh climatic conditions) impede intensive farming, as in many Mediterranean and Boreal regions [3]. In the Iberian Peninsula, one of these systems spreads over thousands of hectares, namely man-made oak (Quercus spp.) savannahs (so called "dehesas" in Spain and "montados" in Portugal) in which livestock rearing is the main land-use form [4]. The presence of trees interspersed within grasslands provides additional food for livestock at the same time that promotes biodiversity [1]. Nonetheless, intensive livestock management is threatening natural tree recruitment and conservation [4-6].

The ecological value of dehesas largely relies on the presence of trees [7-9]. Isolated trees increase the environmental heterogeneity of these ecosystems, allowing the presence of organisms (specially, small ones) that depend on trees in a grassland-dominated landscape $[1,10,11]$. Accordingly, arboreal cover has shown to have a positive impact on arthropods, amongst others [11,12], and house-specific guilds and functional groups [13,14].

The origin of dehesas is semi-natural, with a strong impact of human management [15]. For centuries, humans have cleared evergreen Mediterranean forests and turned them into dehesas designed and managed for livestock farming [4]. Extensive livestock management can be aligned with conservation of dehesas, however, increased livestock density 
jeopardizes the sustainability of these systems [16]. When the number of domestic animals increases too much, acorn predation, lack of seed dispersal by rodents because of their lower density due to the elimination of their shelters (shrubs), and seedling trampling/predation may dramatically reduce natural tree regeneration [16,17]. In the long term, if regeneration of trees completely fails, dehesas could turn into pastures/grasslands with a consequent negative impact on biodiversity (e.g., ants in this study) [18-20].

Previous studies have used ants as indicators of forest disturbances [21-23] by considering their distribution, abundance and diversity [24]. Ants can be also classified according to their food resource utilization or their functional groups. For example, scavenger ants decompose organic matter or living in symbiosis with other animals or plants and perform beneficial functions as soil aeration, organic matter transport, or water retention [21]. Ants have a high functional importance in ecosystems; are sensitive to environmental changes; and are relatively easy to sample, identify, and classify [24]. Thus, interpreting changes on ant community composition is possible to disentangle symptoms of habitat disturbances [24]. Habitat degradation by humans usually entails the partial or total extinction of many organisms. Nevertheless, disturbances rarely provoke disappearance in ants but change their local relative abundance [21].

As ecological indicators, the presence of specific species of ants may indicate a good ecological integrity, but absence is not indicating the opposite. Only the presence of some specific ant species related with human activities can indicate disturbances [21]. The predictive power of individual ant species is low [25], and it is necessary to study ant communities or their behavior [26]. Comparisons among ant communities with low similarity in species composition may inform us about differences in climate, type of soil, and/or vegetation disturbances [25]. The aim of this work is to assess the potential effect of tree loss (by studying the lack of trees) on ant community composition and functional diversity. Comparisons will be performed at different scales to disentangle the effect of trees on these variables. We hypothesized that the presence of oaks offers microhabitats that can be scarce or absent in grasslands. Thus, we expected that functional groups, trophic habits, and community composition of ants nesting in the soil differ between dehesas and grasslands. Within dehesas, we expect to find differences in functional groups and trophic habits of ants nesting in the soil below and outside the tree canopies. Additionally, we expect that ant community composition differs among ants nesting in the soil outside canopy cover, below the canopy, and those inhabiting tree trunk/branches.

\section{Materials and Methods}

\subsection{Study Area}

We carried out the sampling in 8 study sites (Coordinates included in Table S1) of 100 ha each (800 ha in total) from the locality of Trujillo (province of Caceres, Extremadura, southwest of Spain) (Figure 1). Four of these sites were dehesas, with holm oaks (Quercus rotundifolia Lam. = Quercus ilex L. subsp. rotundifolia (Lam.) O.Schwarz) interspersed within a grassland matrix (henceforth "dehesas"). The other four study sites were grasslands/pastures in which trees had been lost due to the lack of regeneration (henceforth "grasslands"). The soil in all study sites is acid, with both low nutrient and organic matter content [27]. The climate is Mediterranean with hot summers; yearly mean temperature of $16^{\circ} \mathrm{C}$, reaching $33^{\circ} \mathrm{C}$ during July and August, and an annual precipitation of $623.1 \mathrm{~mm}$ [28]. 


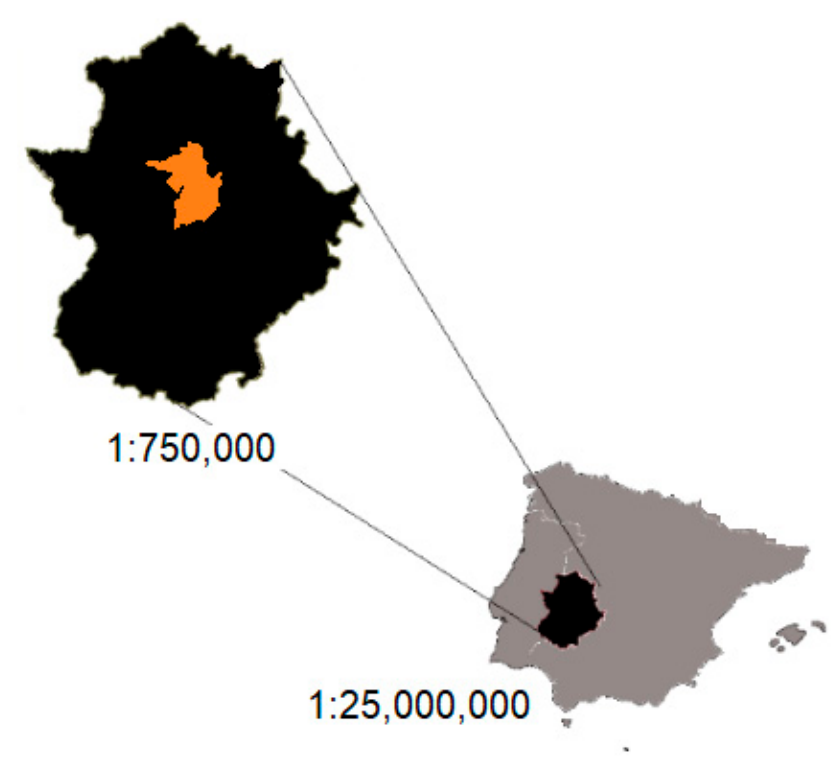

Figure 1. The geographical location of the study area in the Iberian Peninsula (orange).

\subsection{Field Sampling and Material Identification}

To sample ants nesting in the soil, we placed 8 pitfall traps (capacity $175 \mathrm{cc}$ ) per study site. All of them were filled with a mix of $30 \mathrm{cc}$ of alcohol $(70 \%)$ and glycerin in a proportion of $10 \mathrm{~mL}$ of glycerin per $1 \mathrm{~L}$ of alcohol. The minimum distance between traps was $150 \mathrm{~m}$. We set pitfall traps on 15 May 2015 and collected them 5 days later. In total, we placed 32 traps in dehesas and other 32 in grasslands. In dehesas, we placed one trap per site below tree canopy and the other 7 traps were placed in grasslands surrounding the trees (i.e., $>2 \mathrm{~m}$ outside the canopy cover).

To sample arboreal ants, we placed a piece of tuna on the trunk (c. $2 \mathrm{~m}$ above the ground, one per tree) and collected all ants attracted after $1 \mathrm{~min}$ and brushing for an additional $1 \mathrm{~min}$ to a pot with alcohol $70 \%$. We sampled arboreal ants with the attractor in the same 4 oaks in which we placed pitfall traps below canopy. In the laboratory, we sieved samples extracting soil and plant material, and then, we carefully inspected the content and removed all other arthropods except ants. We identified all ants to species level by using the morphological taxonomic keys developed by Gomez and Espadaler [29] and García-García [30]. We identified our material at species level when this was possible (in some specimens, the characters important for species level determination were ripped, smashed, or absent).

We categorized resource specialization as: (i) ants that feed on aphid secretions, (ii) nectivorous, (iii) predators, (iv) scavengers, and (v) granivorous. We categorized functional groups according with the classification proposed by Roig and Espadaler [24] as: (i) cryptic (C), (ii) cold and/or shadow habitat specialists (CCS/SH), (iii) generalist and/or opportunist (GO), and (iv) hot and / or open habitat specialists (HCS/OH). In total, we sampled 8253 individuals from 31 ant species (Table 1) and stored them in the entomological collection of University of Extremadura, Spain (Campus of Plasencia). 
Table 1. Studied material with records of abundance, frequency (number of pitfall traps in which each species was recorded), their functional group (following Roig and Espadaler [24]: $\mathrm{HCS} / \mathrm{OH}=$ hot and/or open habitat specialists, $\mathrm{CCS} / \mathrm{SH}=$ cold and/or shadow habitat specialists, $\mathrm{GO}=$ Generalist and/or opportunist, $\mathrm{C}=$ cryptic), and their main food resource ( $\mathrm{A}=$ aphid secretions, $\mathrm{N}=$ nectar, $\mathrm{P}=$ predator, $\mathrm{S}=$ seeds, $\mathrm{SC}=$ scavenger and ?-Unknown).

\begin{tabular}{|c|c|c|c|c|}
\hline Species & Abundance & Frequency & Guild & Resource \\
\hline Subfamily Myrmicinae & 1402 & 227 & & \\
\hline Messor barbarus & 441 & 53 & $\mathrm{HCS} / \mathrm{OH}$ & S \\
\hline Messor capitatus & 258 & 39 & $\mathrm{HCS} / \mathrm{OH}$ & $S$ \\
\hline Messor bouvieri & 1 & 1 & $\mathrm{HCS} / \mathrm{OH}$ & S \\
\hline Messor lusitanicus & 2 & 1 & $\mathrm{HCS} / \mathrm{OH}$ & S \\
\hline Messor hispanicus & 1 & 1 & $\mathrm{HCS} / \mathrm{OH}$ & $S$ \\
\hline Messor sp. & 2 & 2 & $\mathrm{HCS} / \mathrm{OH}$ & $S$ \\
\hline Aphaenogaster gibbosa & 2 & 1 & $\mathrm{C}$ & $\mathrm{P}, \mathrm{S}, \mathrm{SC}$ \\
\hline Aphaenogaster iberica & 334 & 53 & GO & $\mathrm{P}, \mathrm{S}, \mathrm{SC}$ \\
\hline Aphaenogaster senilis & 9 & 1 & GO & $\mathrm{P}, \mathrm{S}, \mathrm{SC}$ \\
\hline Aphaenogaster dulciniae & 2 & 1 & $\mathrm{C}$ & $\mathrm{P}, \mathrm{S}, \mathrm{SC}$ \\
\hline Tetramorium forte & 162 & 34 & $\mathrm{GO}$ & $S$ \\
\hline Temnothorax sp. & 22 & 11 & $\mathrm{C}$ & $?$ \\
\hline Leptothorax sp. & 12 & 4 & $\mathrm{C}$ & $?$ \\
\hline Crematogaster scutellaris & 108 & 14 & GO & $\mathrm{A}, \mathrm{N}$ \\
\hline Crematogaster auberti & 3 & 2 & GO & $\mathrm{A}, \mathrm{N}$ \\
\hline Goniomma sp. & 7 & 5 & $\mathrm{HCS} / \mathrm{OH}$ & S \\
\hline Oxyopomyrmex sp. & 10 & 3 & $\mathrm{HCS} / \mathrm{OH}$ & $S$ \\
\hline Phelloide pallidula & 26 & 1 & GO & $\mathrm{N}, \mathrm{P}, \mathrm{SC}$ \\
\hline Subfamily Formicinae & 6603 & 152 & & \\
\hline Cataglyphis hispanica & 95 & 39 & $\mathrm{HCS} / \mathrm{OH}$ & SC \\
\hline Cataglyphis iberica & 6 & 4 & $\mathrm{HCS} / \mathrm{OH}$ & SC \\
\hline Cataglyphis sp. & 42 & 16 & $\mathrm{HCS} / \mathrm{OH}$ & SC \\
\hline Formica sanguinea & 9 & 4 & $\mathrm{HCS} / \mathrm{OH}$ & $\mathrm{A}, \mathrm{P}$ \\
\hline Formica subrufa & 6337 & 64 & $\mathrm{HCS} / \mathrm{OH}$ & $\mathrm{A}, \mathrm{P}$ \\
\hline Camponotus cruentatus & 83 & 11 & $\mathrm{HCS} / \mathrm{OH}$ & $\mathrm{A}, \mathrm{N}, \mathrm{P}$ \\
\hline Camponotus pilicornis & 1 & 1 & $\mathrm{HCS} / \mathrm{OH}$ & $\mathrm{A}, \mathrm{N}, \mathrm{P}$ \\
\hline Camponotus sp. & 2 & 1 & $\mathrm{HCS} / \mathrm{OH}$ & $\mathrm{A}, \mathrm{N}, \mathrm{P}$ \\
\hline Lasius brunneus & 16 & 5 & $\mathrm{CCS} / \mathrm{OH}$ & $\mathrm{A}, \mathrm{N}$ \\
\hline Proformica sp. & 12 & 7 & $\mathrm{HCS} / \mathrm{OH}$ & $?$ \\
\hline Subfamily Dolichoderinae & 239 & 51 & & \\
\hline Tapinoma nigerrinum & 200 & 40 & GO & $\mathrm{A}, \mathrm{N}, \mathrm{P}, \mathrm{SC}$ \\
\hline Tapinoma erraticum & 25 & 9 & GO & $\mathrm{A}, \mathrm{N}, \mathrm{P}, \mathrm{SC}$ \\
\hline Tapinoma madeirense & 14 & 2 & GO & $\mathrm{A}, \mathrm{N}, \mathrm{P}, \mathrm{SC}$ \\
\hline TOTAL & 8157 & & & \\
\hline
\end{tabular}

\subsection{Statistical Analyses}

We used a set of Linear Mixed Models (LMMs) to analyze the effect of the type of habitat (dehesa vs. grassland) and microhabitat (below vs. outside canopy) on the number of species of each functional group (i) cryptic, (ii) generalistic and/or opportunistic, and (iii) $\mathrm{HCS} / \mathrm{OH}=$ hot and /or open habitat specialists) in separated models. We did the same to analyze the differences between habitats (dehesa vs. grassland) and microhabitats (below vs. outside canopy) in the number of species of ants that feed on: (i) aphid secretions, (ii) nectar, (iii) other animals (predators), (iv) scavengers, and (v) seeds). In all analyses, the dependent variable was the average number of species per pitfall trap and the site was included as a random factor. To account for different numbers of traps in each site, we divided the average number of species per trap by the number of traps per site (i.e., the total number of species in traps outside canopy was divided by 7 traps outside canopy). 
To assess the degree of species' overlap among ant communities from different habitats and microhabitats, we ran two Principal Component Analyses (PCAs). The first compared grasslands and dehesas, the second compared the ant communities in the open (outside tree canopy), below tree canopy, and on trunks/branches.

All analyses were performed using the statistical software R [31]. To run the GLMMs, we used the function "glmer" implemented in the R-package "lme4" [32]. In the case of PCAs, we used the function "prcomp" implemented in the default R-package "stats."

\section{Results}

\subsection{Differences between Functional Groups}

Overall, we captured a similar number of species in dehesas and grasslands, none of the separate analyses for each functional group showed any difference between these habitats (Figure 2a and Table 2). In both, the most abundant group was that of the ants specialized in warm or open habitats. At scale of microhabitat, within dehesas, we captured a significantly higher number of species below tree canopies than outside them in all functional groups (Figure $2 b$ and Table 2).

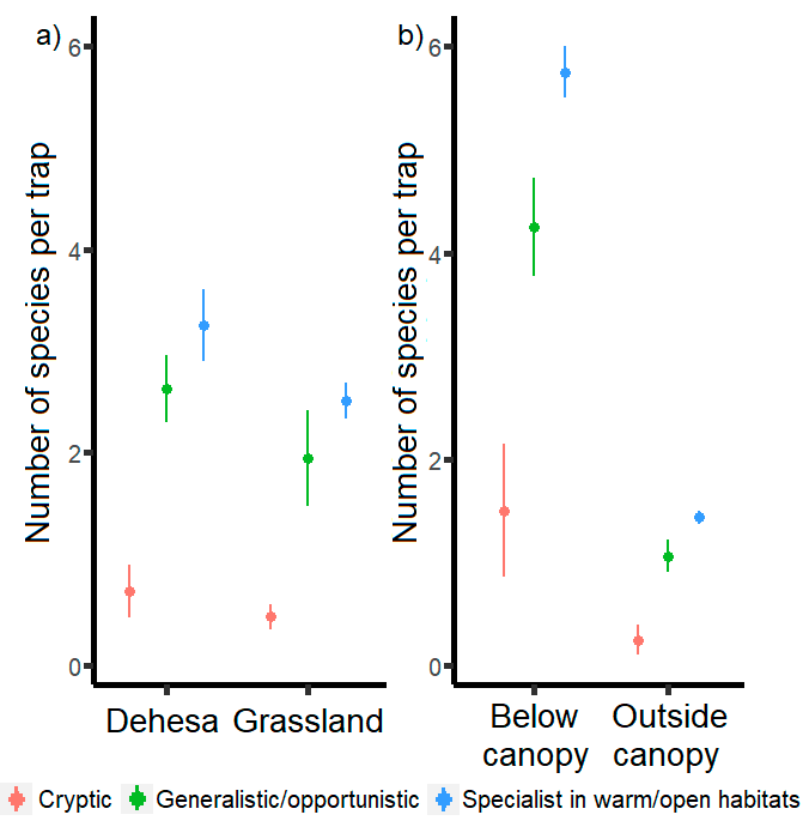

Figure 2. Graph depicting the number of species of soil nesting ants collected per pitfall trap (mean $\pm S E$ ) in: (a) grasslands and dehesas and (b) below and outside tree canopies within dehesas. Different colors represent the different functional groups $(\mathrm{C}=$ cryptic species, $\mathrm{GO}=$ generalists and/or opportunists and $\mathrm{HCS} / \mathrm{OH}=$ specialists in warm and/or open habitats).

Table 2. Differences between habitats (grasslands vs. dehesas) and between microhabitats (below and outside oak canopies within dehesas) in the number of species of the different functional groups $(\mathrm{C}=$ cryptic species, $\mathrm{GO}=$ generalists and $/$ or opportunists and $\mathrm{HCS} / \mathrm{OH}=$ specialists in warm and/or open habitats). Significant $p$-values are shown in bold.

\begin{tabular}{ccccc}
\hline Response Variable & Predictors & $\chi^{\mathbf{2}}$ & df & $p$ \\
\hline \multirow{2}{*}{$\mathrm{C}$} & Grasslands vs. Dehesas & 0.979 & 1 & 0.615 \\
& Below canopy vs. Outside canopy & 4.41 & 1 & $\mathbf{0 . 0 3 6}$ \\
\hline \multirow{2}{*}{$\mathrm{GO}$} & Grasslands vs. Dehesas & 0.42 & 1 & 0.519 \\
& Below canopy vs. Outside canopy & 22.82 & 1 & $<\mathbf{0 . 0 0 1}$ \\
\hline \multirow{2}{*}{$\mathrm{HCS} / \mathrm{OH}$} & Grasslands vs. Dehesas & 0.39 & 1 & 0.531 \\
& Below canopy vs. Outside Canopy & 280.06 & 1 & $<\mathbf{0 . 0 0 1}$ \\
\hline
\end{tabular}




\subsection{Differences between Trophic Groups}

The number of aphid-herding and predator species in dehesas was significantly higher than in grasslands (Figure 3a, Table 3). At the microhabitat scale, within dehesas, we trapped more species of all functional groups below the tree canopy than outside oak cover (Figure 3b, Table 3).
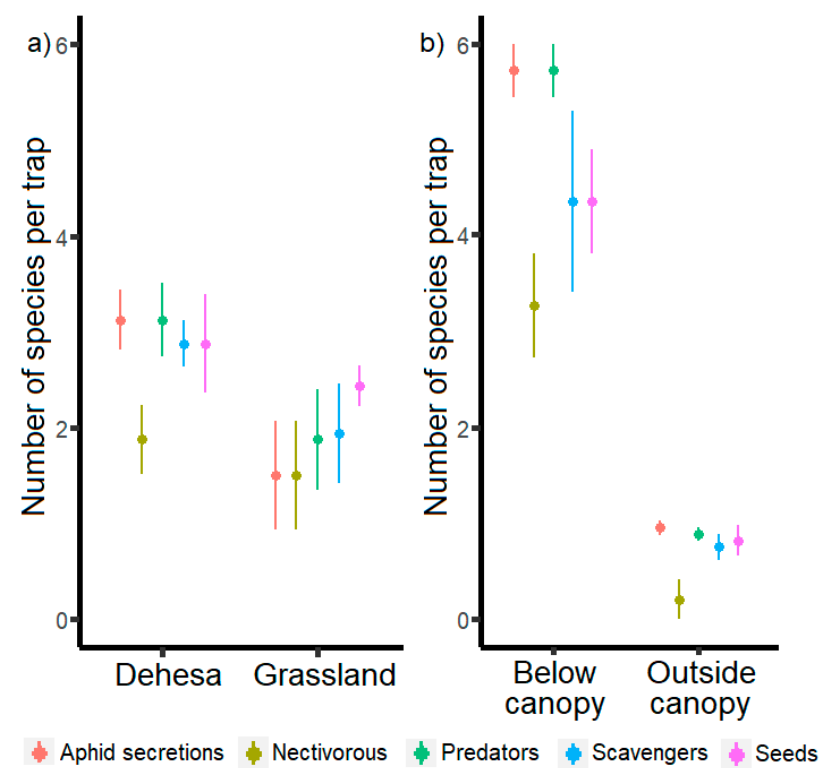

Figure 3. Graph depicting the number of species of soil nesting ants collected per pitfall trap $($ mean $\pm S E$ ) in: (a) grasslands and dehesas and (b) below and outside tree canopies within dehesas. Different colors represent the different trophic groups (ants feeding on aphid secretions, nectivorous, predators, granivorous, and scavengers).

Table 3. Differences between habitats (grasslands vs. dehesas) and between microhabitats (below and outside oak canopies within dehesas) in the number of species of the different trophic groups (ants feeding on aphid secretions, nectivorous, predators, granivorous and scavengers). Significant $p$-values are shown in bold.

\begin{tabular}{ccccc}
\hline Response Variable & Predictors & $\chi^{\mathbf{2}}$ & df & $p$ \\
\hline \multirow{2}{*}{ Aphid secretions } & Grasslands vs. Dehesas & 5.28 & 1 & $\mathbf{0 . 0 4 6}$ \\
& Below canopy vs. Outside canopy & 408.33 & 1 & $<\mathbf{0 . 0 0 1}$ \\
\hline \multirow{2}{*}{ Nectivorous } & Grasslands vs Dehesas & 0.28 & 1 & 0.598 \\
& Below canopy vs. Outside canopy & 27.74 & 1 & $<\mathbf{0 . 0 0 1}$ \\
\hline \multirow{2}{*}{ Predators } & Grasslands vs. Dehesas & 4.74 & 1 & $\mathbf{0 . 0 2 9}$ \\
& Below canopy vs. Outside canopy & 351.70 & 1 & $<\mathbf{0 . 0 0 1}$ \\
\hline \multirow{2}{*}{ Granivorous } & Grasslands vs. Dehesas & 0.38 & 1 & 0.463 \\
& Below canopy vs. Outside canopy & 56.1 & 1 & $<\mathbf{0 . 0 0 1}$ \\
\hline \multirow{2}{*}{ Scavengers } & Grasslands vs. Dehesas & 2.88 & 1 & 0.089 \\
& Below canopy vs. Outside Canopy & 15.63 & 1 & $<\mathbf{0 . 0 0 1}$ \\
\hline
\end{tabular}

\subsection{Assessing Overlap of Ant Communities}

In the two Principal Component Analyses (PCAs), the first component (x-axes) explained $27 \%$ of the variance. In the first PCA, this component segregated grasslands and dehesas, showing differences between habitats (Figure 4a). In the second PCA (analysis at microhabitat level within dehesas), it segregated ant communities outside and below tree canopies (Figure $4 \mathrm{~b}$ ). At level of individual trees, the differences on species composition below the canopies and on the trunk/branches are small (Figure $4 b$ ). 


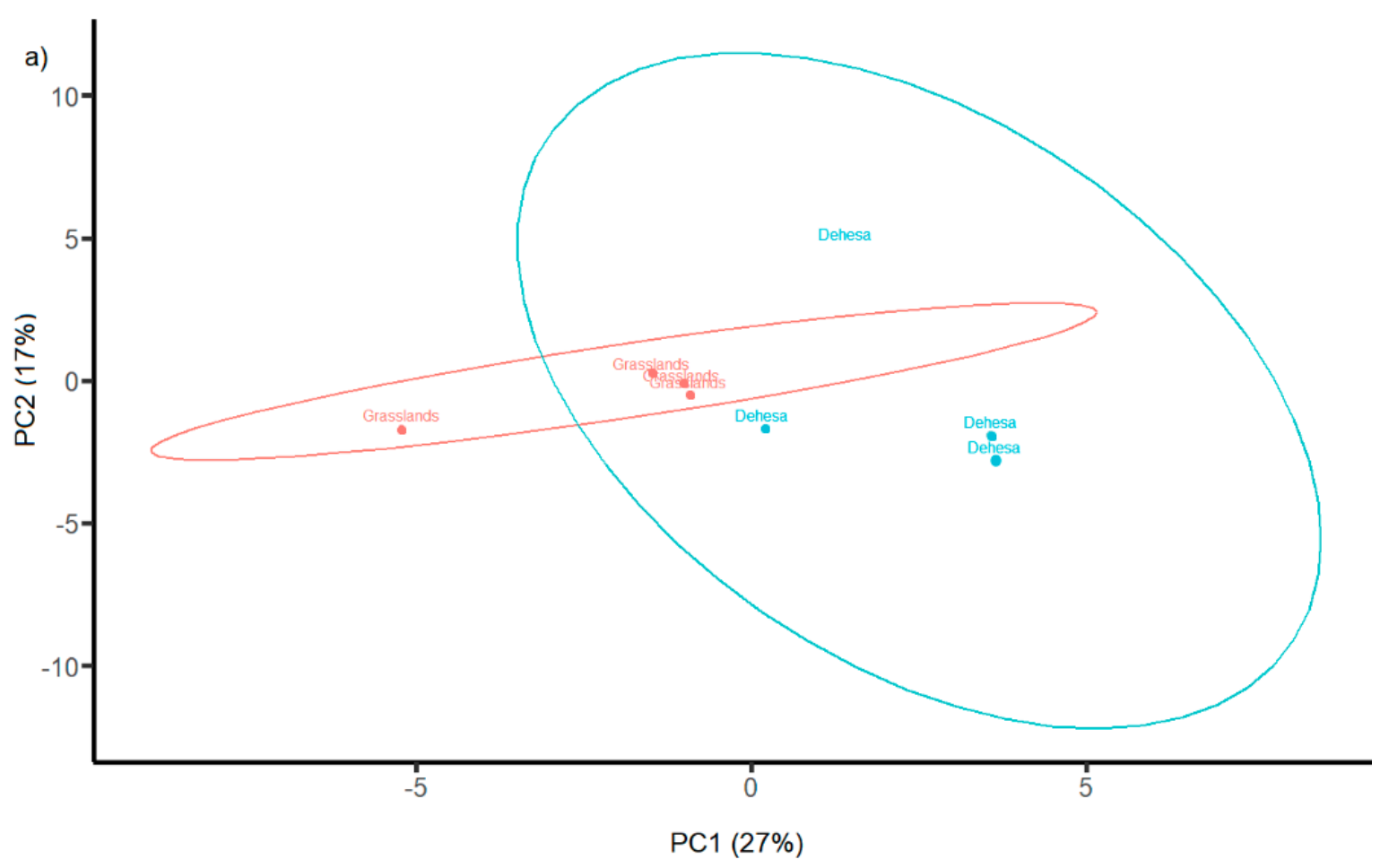

b)

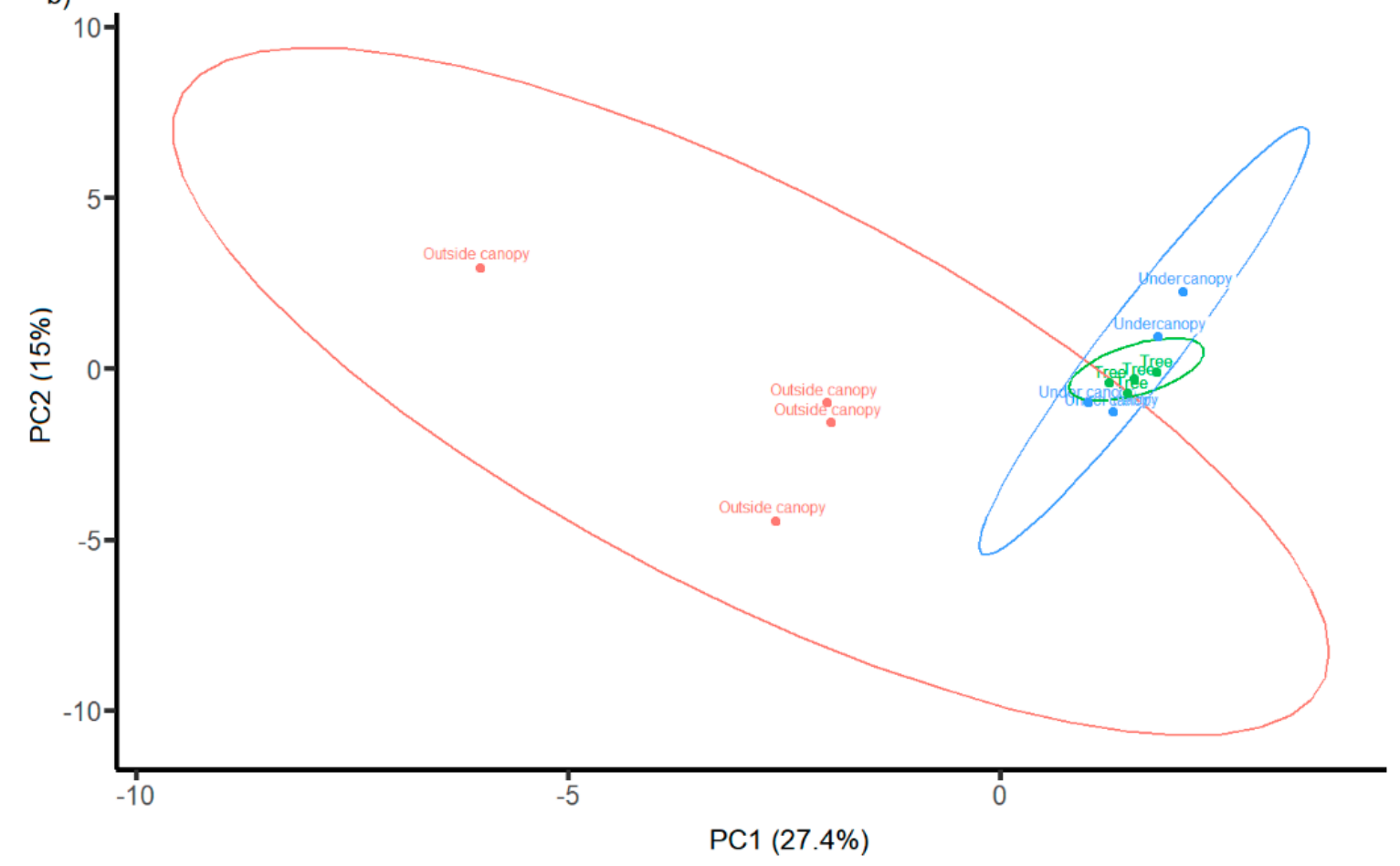

Figure 4. Principal Component Analyses comparing the ant communities from (a) grasslands and dehesas and (b) within dehesas: outside canopy, under canopy, and in the trunk.

Some ant species contributed more to the segregation between habitats than others (those with higher and lower scores in PC1). In the first PCA (showing the differences between grasslands and dehesas), some examples are Crematogaster scutellaris and Formica sanguinea (very positive scores) or Messor barbarous and Messor capitanus (negative scores) (Table S2). In the second PCA (differences between microhabitats within dehesas), those with a stronger effect in the separation along the PC1 axis were Crematogaster scutellaris, 
Cataglyphis hispanica (positive scores), Messor capitanus, and Goniomma sp. (scores below zero) (Table S3).

\section{Discussion}

Our results show that the presence of oaks increases the number of ant species within dehesas. Irrespective of the functional group or trophic specialization, the number of soilnesting species collected per pitfall trap was higher below the tree canopies than outside oak cover. When the dehesas were compared against treeless grasslands, there were significant differences in the number of species of aphid-herding and predator ants.

We collected 31 morphospecies out of the 57 species reported by Gomez and Espadaler [29] for the province of Caceres (the same province in which our study was carried out). Moreover, our sampling added a new record (Aphaenogaster dulciniae) not only for Caceres, but for the Region of Extremadura. We captured a high number of species linked to dehesas, however, the province of Caceres has a significant environmental variability (including not only oak savannahs/forests but also high mountain ecosystems or wetlands) that can house other species that are not present in dehesas. The dominancy of Formica subrufa could be explained by its gregarious habits and its high level of activity [29]. At the subfamily level, Myrmicinae had the highest number of species followed by Formicinae and Dolichoderinae. Since we did not use baits or attractors for ants nesting in the soil, the presence of species with specific food preference may be under-estimated [21]. In addition, predatory species might be not be fully represented either, because, usually, they stay hidden while stalking preys [21]. Nonetheless, as the trapping methodology was the same for habitats and microhabitats, such potential deviations cannot account for the differences found. However, we prudently interpreted our contrasts on microhabitats due the low number of traps below canopies.

The overall dominance of ants specialized in warm or open habitats did not differ from that expected for an area of Mediterranean climate with dry summers. The most abundant species, Formica subrufa, belongs to this functional group. In the second place, we recorded generalist/opportunistic species (e.g., Aphaenogaster spp., Crematogaster spp., and Tapinoma spp.), which are generally indicators of disturbance [24]. This could be due to the centuries-long human use of dehesas and grasslands, as high livestock densities reduce vegetation cover and erode the soil [4].

Trophic specialization differed between habitats, predator, and aphid-herding species being significantly more abundant in dehesas. Within dehesas, these species were mainly trapped on the trunks or beneath the oak canopies. Previous samplings in Mediterranean orange orchards have also found this link between aphid-herding ants and trees [33]. Some of the species recorded in those studies, like Crematogaster spp., were also common in oaks. They nest beneath the bark, in wood hollows or in nests abandoned by other arthropods [34]. Other aphid herders as Camponotus spp. were more abundant in dehesas and, more specifically, below oak canopies (positive scores in the first axis of the two PCAs). This species is commonly collected on trunks too, as their nests may be placed either under the litter or within tree hollows/crevices [34]. The same is valid for Formica subrufa, a species superabundant in dehesas [35]. This species, endemic of Iberian Peninsula and southern France, nests beneath stones and is linked to oak forests (more or less degraded) or other woody habitats (e.g., heathlands Erica spp.) [36]. They prey on arthropods [37], but also feed on aphid secretions.

Differences in species composition could indicate that, in our study sites, aphids are restricted to areas with trees and also sampling dates might affect the presence of some aphid species. In mid-May, temperatures are usually high already, and grass has started to dry up. Aphids feed on phloem sap, which is lacking in dry herbs. Hence, from then on, that food resource would only be available for aphids in new oak shoots. Accordingly, multi-spectral images have shown that, during the drought period, the photosynthetic activity is restricted to the trees in dehesas [38]. Thus, we cannot know whether aphidherding species could be more spread outside the tree canopies in other periods of the year, 
although this seems unlikely. Suay-Cano et al. [33] showed that aphid-ant relationship is very specific, so that ants would not be expected to move too much from trees unless their target aphid species does so.

Granivorous Messor spp. were more prevalent in treeless grasslands. This could be due to the effect of canopy shade or livestock activity, which reduces the availability of grass seeds $[9,11]$. Within dehesas, Messor spp. were more abundant in the open than below the tree canopies. These ants are common in grasslands, savannahs, semi-deserts/deserts [39] and also in arable fields, where they may provoke major seed losses [40]. However, further studies have shown that the negative impact is not so high and they have a beneficial role as weed controllers and granivorous ants [41,42].

To conclude, our study supports the role of trees as keystone structures in agroecosystems [1]. Trees offer a new microhabitat (food resources/refuges) for species that would otherwise be absent in treeless grasslands. In Iberia, further comparisons of ant communities between self-standing oaks in wood pastures versus nearby oak forests are needed (see [43] for a similar study in Central Europe). Such studies could show whether some species are only present or more abundant in oak savannahs because they do not tolerate well closed canopy conditions. Previous studies have addressed the role of trees for arthropod conservation in temperate wood pastures in other European areas [18-20,43]. However, to the best of our knowledge, this study has addressed, for the first time, the reasons underlying ant species segregation in Iberian dehesas. So far, differences in ant communities below and outside tree canopies had been attributed to the degree of shade tolerance [44], but not analyzed according to functional groups or trophic habits. Our results stress the importance of the heterogeneous vegetation structure of Iberian oak savannahs not only for livestock productivity $[4,45]$ but also for biodiversity conservation.

Supplementary Materials: The following are available online at https:/ / www.mdpi.com/1424-281 8/13/3/115/s1, Table S1: Coordinates (in decimal degrees) from sampled areas, Table S2: PC1 and PC2 output values for each species corresponding with the PCA analysis from Figure 4a, Table S3: PC1 and PC2 output values for each species corresponding with the PCA analysis from Figure 4b.

Author Contributions: Conceptualization, G.G.-B. and G.M.; methodology, G.G.-B. and G.M.; formal analysis, Á.G. and R.B.; data curation, J.L.B.; writing-original draft preparation, Á.G. and R.B.; writing-review and editing, Á.G. and R.B.; supervision, G.G.-B. and R.B.; project administration, G.G.-B. and G.M.; funding acquisition, G.M. All authors have read and agreed to the published version of the manuscript.

Funding: This work received financial support from the project AGFORWARD (AGroFORestry that Will Advance Rural Development) founded by European Union's Seventh Framework Programme for Research and Technological Development (FP7) with the number 613520.

Institutional Review Board Statement: Not applicable.

Informed Consent Statement: Not applicable.

Data Availability Statement: All original specimens are preserved on the entomological collection of University of Extremadura (Campus of Plasencia).

Acknowledgments: We acknowledge to Francisco Martín Azcárate for reviewing the morphological classification of our samples. We thank the comments of 3 anonymous reviewers that helped to improve this document.

Conflicts of Interest: The authors declare no conflict of interest.

\section{References}

1. Manning, A.D.; Fischer, J.; Lindenmayer, D.B. Scattered trees are keystone structures-Implications for conservation. Biol. Conserv. 2006, 132, 311-321. [CrossRef]

2. Luedeling, E.; Kindt, R.; Huth, N.I.; Koening, K. Agroforestry systems in a changing climate-Challenges in projecting future performance. Curr. Opin. Environ. Sustain. 2014, 6, 1-7. [CrossRef]

3. Mosquera-Losada, M.R.; Moreno, G.; Santiago-Freijanes, J.J.; Ferreiro-Dominguez, N.; Rigueiro-Rodriguez, A. Sistemas agroforestales y PAC. Rev. Ambient. 2015, 112, 110-124. 
4. Pulido, F.; Picardo, A.; Campo, P.; Carranza, J.; Coleto, J.M.; Díaz, M.; Dléguez, E.; Escudero, A.; Ezquerra, F.J.; Lopez, L.; et al. Libro Verde de la Dehesa: Universidad de Extremadura. 2010. Available online: http://www.eweb.unex.es/eweb/ accionporladehesa/documentos/libro_verde_dehesa.pdf (accessed on 2 October 2020).

5. Namirannian, M.; Henaerht Khalyani, A.; Zahedi Amiri, G.; Ghazanfari, H. Study of different restoration and regeneration techniques in northern Zagros (Case study: Amardeh oak forest, Baneh). Iran. J. Nat. Resour. 2007, 15, 386-397.

6. Wassie, A.; Sterck, F.J.; Taketay, D.; Bongers, F. Effects of livestock exclusion on tree regeneration in church forests of Ethiopia. For. Ecol. Manag. 2009, 257, 765-772. [CrossRef]

7. Alexander, K. The invertebrates of Britain's woodlands. Br. Wildl. 1999, 11, 108-117.

8. Dunn, R.R. Isolated trees as foci of diversity in active and fallow fields. Biol. Conserv. 2000, 95, 317-321. [CrossRef]

9. Plieninger, T.; Pulido, F.J.; Konorld, W. Effects of land-use history on size structure of holm oak stands in Spanish dehesas: Implications for conservation and restoration. Environ. Conserv. 2003, 30, 61-70. [CrossRef]

10. Benton, T.G.; Vickery, J.A.; Wilson, J.D. Farmland biodiversity: Is habitat heterogeneity the key? Trends Ecol. Evol. 2003, 18, 182-188. [CrossRef]

11. Tews, J.; Brose, U.; Grimm, V.; Tielbörger, K.; Wichmann, M.C.; Schwager, M.; Jeltsch, F. Animal species diversity driven by habitat heterogeneity/diversity: The importance of keystone structures. J. Biogeogr. 2003, 31, 79-92. [CrossRef]

12. Gaytán, A.; Ricarte, A.; González-Bornay, G. Hoverfly diversity (Diptera: Syrphidae) of Pyrenean oak woodlands in Central-Western Spain: A preliminary study with conservation outcomes. J. Insect Conserv. 2020, 24, 163-173. [CrossRef]

13. Telleria, J.L.; Santos, T. Distribution of birds in fragments of Mediterranean forests: The role of ecological densities. Ecography 1999, 22, 13-19. [CrossRef]

14. Vehviläinen, H.; Koricheva, J.; Ruohomäki, K. Effects of stand tree species composition and diversity on abundance of predatory arthropods. Oikos 2008, 117, 935-943. [CrossRef]

15. Cano-Ortiz, A.; Musarella, C.M.; Piñar-Fuentes, J.C.; Quinto-Canas, R.; Pinto-Gomes, C.J.; Spampinato, G.; Ighbareyeh, J.M.H.; Del Río, S.; Cano, E. Forest and arborescent scrub habitats of special interest for SCIs in Central Spain. Land 2021, 10, 183. [CrossRef]

16. Mosquera-Losada, M.R.; Regueiro-Rodríguez, A.; McAdam, J. Silvopastoralism and Sustainable Land Management; CABI Publishing: Wallingford, UK, 2005.

17. Canelo, T.; Pérez-Izquierdo, C.; Gaytán, Á.; Bonal, R. Intraguild predation o weevils by livestock reduces acorn pests in oak silvopastoral systems. J. Pest Sci. 2021, 94, 541-551. [CrossRef]

18. Dolek, M.; Freese-Hager, A.; Bussler, H.; Floren, A.; Liegl, A.; Schmidl, J. Ants on oaks: Effects of forest structure on species composition. J. Insect Conserv. 2009, 13, 267-375. [CrossRef]

19. Falk, S. Wood-Pastures as Reservoirs for Invertebrates: In European Wood-Pastures in Transition: A Socialecological Approach; Hartel, T., Plieninger, T., Eds.; Routledge: Abingdon, UK, 2014.

20. Sebek, P.; Vodka, S.; Bogusch, P.; Pech, P.; Tropek, R.; Weiss, M.; Zomova, K.; Cizek, L. Open-grown trees as key habitats for arthropods in temperate woodlands: The diversity, composition, and conservation value of associated communities. For. Ecol. Manag. 2016, 380, 172-181. [CrossRef]

21. Miguelena, J.G. Estructura y Composición de las Comunidades de Hormigas en Ambientes Contrastantes en el Parque Estatal Flor del Bosque en Amozoc de Mota, Puebla. Doctorado, Universidad de las Américas, Puebla, Chile, 2008.

22. Fuster, A. Hormigas (Hymenoptera: Formicidae), Indicadoras de Perturbación en un Ecosistema Forestal, en el Chaco Semiárido Argentino. Doctorado, Universidad Nacional de Tucumán, Tucumán, Argentina, 2013.

23. Herraiz-Cabello, J.A. Estudio de las Comunidades de Hormigas de los Diferentes tipos de Vegetación del Parc Natural de Sant Llorenc del Munt i l'Obac. Doctorado, Universidad Autónoma de Barcelona, Bellaterra, Spain, 2010.

24. Roig, X.; Espadaler, X. Propuesta de grupos funcionales de hormigas para la Península Ibérica y Baleares, y su uso como bioindicadores. Iberomyrmex 2010, 2, 28-29.

25. Arcila, A.M.; Lozano-Zambrano, F.H. Hormigas como herramienta para la bioindicación y el monitoreo. In Introducción a las Hormigas de la Región Neotropical; Fernández, F., Ed.; Instituto de Investigación de Recursos Biológicos Alexander von Humboldt: Bogotá, Colombia, 2003; Volume 26, p. 398. ISBN 958-8151-23-6.

26. Andersen, A.N. Using Ants as bioindicators: Multiscale Issues in Ant Community Ecology. Conserv. Ecol. 1997, 1, 17. [CrossRef]

27. ADICOMT. Programa Comarcal de Desarrollo Rural Comarca Miajadas-Trujillo. Trujillo-Miajadas 2017-2013: Gobierno de Extremadura. 2013. Available online: http://rurex.juntaextremadura.es/documentos/estra_comarcales/adicomt.pdf (accessed on 4 December 2020).

28. AEMET. Atlas Climático Ibérico: Agencia Estatal de Meteorología. 2011. Available online: http:/ /www.aemet.es/documentos/ es/conocermas / publicaciones / Atlas-climatologico/Atlas.pdf (accessed on 4 December 2020).

29. Gomez, K.; Espadaler, X. Hormigas Ibéricas. 2007. Available online: http:/ / www.hormigas.org/ (accessed on 10 September 2020).

30. García-García, F. Claves de Obreras de Cataglyphis (Foerster, 1850) (Hymenoptera, Formicidae) de la Península Ibérica, con Banco de Imágenes, Siguiendo el Trabajo “Proyecto Fauna Ibérica. Familia Formicidae" de Mª Dolores Martínez-Ibáñez y Alberto Tinaut. Asociación Ibérica de Mirmecología. 2015. Available online: http://www.lamarabunta.org/videos/Claves\%20cataglyphis\%20 ibericas.pdf (accessed on 10 September 2020).

31. R Core Team. R: A Language and Environment for Statistical Computing; R Foundation for Statistical Computing: Vienna, Austria, 2020; ISBN 3-900051-07-0. Available online: http:/ / www.R-project.org/ (accessed on 3 February 2020). 
32. Bates, D.; Mächler, M.; Bolker, B.; Walker, S. Fitting Linear Mixed-Effects Models Using lme4. J. Stat. Softw. 2015, 67. [CrossRef]

33. Suay-Cano, V.A.; Tinaut, A.; Selfa, J. Las hormigas (Hymenoptera, Formicidae) asociadas a pulgones (Hemiptera, Aphididae) en la provincial de Valencia. Graellsia 2011, 58, 21-37. [CrossRef]

34. Majer, J.D.; Delabie, J.H.C. Impact of tree isolation on arboreal and ground ant communities in cleared pasture in the Atlantic rain forest region of Bahia, Brazil. Insectes Sociaux 1999, 46, 281-290. [CrossRef]

35. Cavia, V. Formica Subrufa, Rover 1859 (Hymenoptera: Formicidae) Aportación al Studio de su Ecología y Etología. Tesis de Licenciatura, Universidad Autónoma de Barcelona, Bellaterra, Spain, 1988.

36. Tinaut, A. Descripción del macho de Formica subrufa Roger, 1859 y creación de un nuevo subgénero (Hymenoptera: Formicidae). EOS. Rev. Esp. Entomol. 1990, 65, 281-291.

37. De Haro, A.; Collingwood, C.A. Prosprección mirmecológica de la Cordillera Ibérica. Osiris 1991, 6, 109-126.

38. Pérez-Izquierdo, C.; Canelo, T.; Gaytán, A.; Bonal, R. Drones, satélites y dispositivos GPS: Tecnología para una gestión innovadora de la dehesa. Solo Cerdo Ibérico 2018, 40, 77-88.

39. Bolton, B. Afrotropical species of the myrmecine ant genera Cardiocondyla, Leptothorax, Melissotarsus, Messor and Cataulacus (Formicidae). Bulletin of the British Museum (Natural History). Entomology 1982, 46, 307-370.

40. Westerman, P.R.; Atanackovic VRoyo-Esnal, V.; Torra, J. Differential weed seed removal in dryland cereals. Arthropod-Plant. Interact. 2012, 6, 591-599. [CrossRef]

41. Arnan, X.; Molowny-Horas, R.; Rodrigo, A.; Retana, J. Uncoupling the effects of seed predation and seed dispersal by granivorous ants on plant population dynamics. PLoS ONE 2012, 7, e42869. [CrossRef] [PubMed]

42. Baraibar, B.; Ledesma, R.; Royo-Esnal, A.; Westerman, P.R. Assessing yield losses caused by the harvester ant Messor barbarous (L.) in winter cereals. Crop. Prot. 2011, 30, 1144-1148. [CrossRef]

43. Tausan, I.; Muraru, I.M.; Öllerer, K. Monitorin ant assemblages of oak wood-pastures. A case of study from Eastern Europe. Biologia 2021. [CrossRef]

44. Reyes-Lopez, J.; Ruiz, N.; Fernández-Haeger, J. Community structure of ground-ants: The role of single trees in a Mediterranean pastureland. Acta Oecologica 2003, 24, 195-202. [CrossRef]

45. Tejerina, D.; García-Torres, S.; Cabeza de Vaca, M.; Vázquez, F.M.; Cava, R. Acorns (Quercus rotundifolia Lam.) and grass as natural sources of antioxidants and fatty acids in the "montanera" feeding of Iberian pig: Intra- and inter-annual variations. Food Chem. 2011, 124, 997-1004. [CrossRef] 